continue then several problems need to be resolved Firstly, it may be prudent to adhere to the recommendations made in the 1979-81 confidential inquiry into maternal morbidity ${ }^{12}$ and establish one or more teams in the receiving hospitals with expertise in managing such conditions as worsening pre-eclamptic toxaemia. Advice could then be given before transfer. Secondly, the receiving hospitals must continue to encourage both medical and midwifery staff to maintain their abilities to deal with severely ill mothers who are highly dependent, as routinely accepting compromised patients will inevitably lead to an increase in the incidence of maternal morbidity.

Whichever option is chosen, however, it seems that a much fuller assessment of the risks to the mother must be undertaken before transfer. In many cases these may outweigh the risks to the fetus.

1 Chiswick ML. Perinatal referral: a time for decisions. Br.Med $\mathcal{f}$ 1982;285:83-4 2 Cooke RWI. In utero transfer to specialist centres. Arch Dis Child 1983;58 483-4.
3 Blake AM, Pollitzer MJ, Revnolds EOR. Referral of mothers and infants for intensive care. Br.Med f 1979;ii:4lt-6.

+ Modanlou HD, Dorchester W, Freeman RK, Rommal C. Perinatal transpor to a regional perinatal centre in a metropolitan area: maternal versus to a rginal perinata 70 (138:1157-64.

5 Crowley P, Lamont R, Elder MG. The obstetric care of the foetus transferred in utero. Foumal of Obstetrics and (ivnaecology 1982:2:129-33.

6 Lobb MO, Morgan MEI, Bond AP, Cooke RWI. Transfer before delivery on Merseyside: an analysis of the first 140 patients. Br $\mathcal{F}$ Obstet Gynaecol $1983 ; 90: 338-41$

7 Wood B, Catford JC, Cogswell JJ. Confidential paediatric inquiry into neonatal death in Wessex, 1981 and 1982. Br.Med $\mathcal{F} 1984 ; 288: 1206-8$.

8 Beverley D, Foote K, Howel D, Congdon P. Effect of birthplace on infants with low birth weight. Br Med f 1986;293:981-3.

9 Watkinson M, McIntosh N. Outcome of neonatal intensive care: obstetric implications for a regional service. Br f Obstet Gynaecol 1986;93:711-6.

10 Powell TG, Pharoah POD. Regional neonatal care: bias and benefit. Br Med f 1987:295:690-2.

11 Chiswick ML, Davies P, Dryburgh E, Gordon-Nesbitt D. Regional organisation of neonatal intensive care in the north-west. $\mathrm{Br} \mathrm{Med} \mathrm{f}$ 1979;ii:247-50.

12 Turnbull AC, Tindall VR, Robson G, Dawson IMP, Cloake EP, Ashlev JSA. Repurt into confidential enquiries into maternal death in England and Wales Repurt into confudential enquiries into maternal death in England and Wales
1979-1981. London: HMSO, 1986:20-1. (Report on health and social subjects No 29.)

(Accepted 21 September 1989)

\title{
Monitoring and evaluating Working for Patients
}

\section{Ken Judge}

Each new piece of information made available by the Department of Health about the detailed implementation of Working for Patients emphasises the magnitude of the changes facing the NHS in the run up to 1991. The passage of time since the proposals were first announced, however, has done little to assuage the fear that many of them represent a giant leap into the unknown. Many commentators, therefore, have been disappointed at the government's antagonism to a more evaluation oriented approach. There is some evidence of a growing recognition in ministers that learning by doing must be an integral part of the reform process. But there is little support in Whitehall for comprehensive monitoring and evaluation of the changes that have been set in train.

Against this background the King's Fund has decided to support independent assessments of the government's proposals. National advertisements were placed in the specialist press during the summer to encourage outline research applications from a wide variety of sources; 78 were subsequently received and considered. A short list of 13 was selected and investigated in more detail. The King's Fund has decided to invest about $\$ 500000$ over the next two to three years on five of these projects, and further consideration is being given to another two.

The five research projects, which are summarised below, will form the centrepiece of the fund's efforts to monitor and evaluate the implementation of Working for Patients. This activity will be coordinated by the King's Fund Institute and will include close observation of the forthcoming legislative process and the gathering of wider intelligence about relevant research and development activity throughout the NHS.

The King's Fund is supporting research on the following topics:

- The introduction of managed competition in one NHS region

- The development of selected budget holding general practices

- The implementation and use of clinical audit in the specialty of general medicine

- Changes in patients' and general practitioners' satisfaction with access to hospitals for "cold surgery"
- The impact of Working for Patients on elderly people.

The Fund is also considering research aimed at investigating the impact of the white paper on administrative and labour costs in hospitals and management of staffing in the NHS.

\section{MANAGED COMPETITION}

Managed competition in health cares lies at the heart of the government's future strategy for the NHS. A key assumption is that separating the purchase of health care from its provision will stimulate competition between providers so as to:

- Increase cost sensitivity

- Improve efficiency

- Encourage innovation and enterprise

- Raise quality standards.

Research by the National Association of Health Authorities aims at monitoring the introduction of managed competition in the West Midlands region over three years. The project has four main aims.

- Firstly, it will monitor changes in the scale and pattern of service provision. This will entail documenting changes in flows of patients and service patterns such as the type, volume, and location of services offered by providers

- Secondly, the research will subject the theory of managed competition to empirical test. The full effects will not become apparent over the relatively short life of the project. Nevertheless, there will be strong indications of its direction, and it will be possible to identify trends and different management approaches - Thirdly, the work of the National Association of Health Authorities will contribute to management learning and the management of change. Information on best practice and innovation on such issues as contract construction, performance evaluation, and price setting will be made available to managers and clinicians as the research progresses

- Finally, the project will develop more precise and reliable instruments and indicators to aid long term 
monitoring. Many of the problems associated with the introduction of managed competition rest on the absence of reliable agreed measures, such as quality. Inevitably the measures and indicators used initially will be fairly crude. By taking an "action learning" approach the National Association of Health Authorities hopes to refine these.

\section{GENERAL PRACTICE BUDGETS}

The government's proposed experiment with general practice budgets is both one of the most innovative and problematic in Working for Patients. It has the potential to change the incentive structure within the service beneficially by rewarding effective hospital departments with more cash, by putting the financial leverage nearer the consumer, and by giving greater freedom to general practitioners to undertake work themselves or contract with specialist agencies. There are also incentives to prescribe in a cost effective way.

Yet there are also real dangers of inadvertently establishing perverse incentives. For example, any practitioner faced with an absolute budget constraint has a strong incentive to seek a less costly mix of patients. A greater understanding of these pressures and the differential demands that various categories of patients put on the practice would make it possible to build incentives that compensate for these factors into the formula that determines a practice budget.

In short, there is a strong theoretical as well as a practical case for studying the way practices actually respond to the incentive structure of an enhanced practice budget. This is what Howard Glennerster, professor of social policy at the London School of Economics, proposes to do. Through several case studies his project will monitor the process of change and prepare the ground for later work on outcomes.

There will be three phases to the research. In the first year the emphasis will be on monitoring discussions in eight practices that are contemplating opting for enhanced budgets. Once it becomes clear which of the practices has definitely opted for the new budget arrangements, four will be chosen for in depth study along with two "controls." The research focus in the four experimental sites will then move to monitoring the process of adaptation to the new management situation, the issues that were faced, and how they were resolved and the financial and management structures that were put in place. This will be compared with control practices. The third and overlapping phase will entail using the practices' own information systems to develop preliminary outcome indicators.

\section{CLINICAL AUDIT}

Ensuring that consultants are properly accountable for the consequences of their clinical decisions is one of the main themes of Working for Patients. A key mechanism for achieving this is medical audit.

Martin Buxton and his colleagues at Brunel University are planning to monitor the development of medical audit in acute hospitals through an in depth study of general medicine at several selected sites. Their study proposes to address four basic questions about medical audit.

- The first and most crucial question concerns the purposes of medical audit. It might be carried out for any or all of the following reasons: to inform professional practice; for the "management" of a specialty or service; for strategic purposes linked to the objectives of the hospital; and as a contribution to the quality assurance element of a service contract

- The second question concerns the organisational arrangements. This part of the research will focus on the changing nature of the relationship between doctors and managers

- The third question concerns the information requirements for medical audit. Currently, it is not clear how best to collect reliable clinical data and how to help doctors to collect and interpret it

- The fourth question is that of who defines and monitors the standards set for medical audit. Working paper 6 on medical audit suggests that both the government and the royal colleges will be involved, but their respective roles remain unclear. Similarly, at the local level the role of the proposed district medical advisory committees remains to be defined.

\section{PATIENT CHOICE}

There is a clear belief within the government that the implementation of Working for Patients will increase choice for general practitioners and their patients by making hospitals more responsive to the needs and wishes of consumers and encouraging quality and efficiency. Non-urgent surgical procedures are commonly cited as examples of where the new system will work best. Many general practitioners and organisations representing patients' interests have, however, expressed fears that the imposition of contracts could restrict choice for individual patients and their general practitioners. They have argued that general practitioners' current freedom to refer patients to any hospital or consultant will be eroded. They are not convinced that the existence of a contingency fund for referrals outside of the negotiated contracts provides adequate protection.

The centre for primary health care research at the University of Manchester will evaluate changes to the way in which referrals to hospital are made and their consequences for patients. It focuses on general practitioner referrals to hospital for cold surgery, for which the scope for choice of hospital seems to be greatest. There are five specific objectives.

- Firstly, to describe the range of options potentially available to general practitioners and patients under the present system

- Secondly, to describe the choices general practitioners are able to offer to patients, patients' perceptions of these, the factors concerned in deciding between alternatives, and the extent of demand for greater choice under the present system

- Thirdly, to describe general practitioners' experiences and perceptions of choice and the factors concerned in making decisions under the present system

- Fourthly, to describe the range of options potentially available to general practitioners and patients one year after the implementation of hospital contracts

- Finally, after implementation of hospital contracts, to assess the impact on patient satisfaction of changes to the system.

\section{IMPACT ON THE ELDERLY}

The fifth King's Fund project, which is based at the University of Wales College of Medicine, aims at monitoring the impact of the white paper on elderly people. By using material collected from random samples of the elderly population in several health districts the project will investigate possible changes in:

- The demand for health care

- Access to general practice

- The use of medication

- Hospital discharge procedures.

The demand on health services will be monitored by 
measuring use of services and by numbers on waiting lists and duration of waiting. The health status of the population will also be measured-by previously validated scales for functional disability, anxiety and depression, memory impairment, acute and chronic illness - to enable standardisation and to monitor possible changes.

In primary health care the study will monitor access to and availability of services, surgery hours, appointment systems, use of nurse and deputising services, screening policies, waiting times, frequency of surgery and home visits, and use of accident and emergency departments and patients' opinions of these services.

The study will also monitor the total amount of drugs prescribed per person, their cost and appropriateness, the use of repeat prescriptions, self medication, and people's understanding of the drugs they take.

The fourth part of the research (monitoring hospital discharge practice) will be based on random samples of patients in three health districts. Shortly after discharge from hospital these patients will be sent a postal questionnaire, which will inquire about discharge procedures, preparation for discharge, and contact with statutory and voluntary community services and informal carers and will also investigate patients' opinions of their hospital stay and discharge procedures.

\section{Networking}

The Kings' Fund Institute intends to establish a network of researchers concerned with monitoring the implementation of the NHS reforms. If there is sufficient interest the institute will put some effort into developing a register and acting as a clearing house for relevant research and development activity. The institute would be grateful, therefore, for information from anyone engaged in or planning to monitor or evaluate the transformation of the NHS that is now taking place. A conference to consider the research implications of Working for Patients is being planned for the spring.

The King's Fund Institute is an independent centre for health policy analysis.

\section{BOOKS RECEIVED}

\section{Medical education}

Simulation of Initial Medical ProblemSolving: Studies on a New Measure for the Assessment of Medical Solving thility. E de Graff. Problem Solving Ability. E de Graaff. (Pp ix $109 ; £ 13$ paperback.) Amsterda
Thesis, 1989. ISBN 90-5170-006-7.

\section{Medical ethics}

Doctors' Decisions: Ethical Conflicts in Medical Practice. Ed GR Dunstan, E A Shinebourne. Pp $x+248$ \{22.50.) Oxford: Oxford Universi

Press, 1989. ISBN 0-19-261631-5.

\section{Neurology}

Human Horizons Series. "Alzheimer's Disease: Coping with a Living Disease: Coping with a Living
Death." R T Woods. Pp 232; £7.95 paperback. London: Souvenir Press, paperback.) London: Souv
1989. ISBN 0-285-65038-6.

Neurological Disease and Therapy. Vo . "Familial Alzheimer's Disease Molecular (ienetics and Clinica Perspectives." Ed G D Miner, R W Richter, JP Blass, $e t$ al. Series editor W C Koller. $(P p+20$; figs: $\$ 150$. New York: Dekker, 1989. ISBN 0-82478068-X.

Neurological Emergencies. SD Shorvon. Pp xi + 108; figs; $£ 5.9$ paperback., London: Butterworth Scientific, 1989. ISBN 0-407 00873-X.

\section{Nursing}

Education for Care Series. "Furthe Research for Nursing: a New (iuid for the Enquiring Nurse." Ed JM Clark, L. Hockey. (Pp xi +180; 17.50 paperback. London: Scutari, 1989 ISBN 1-87136+-14-0.

Nursing a Problem. L Mackay. Pp viii 200 ; 29.95 paperback.) Milton Kevnes: Open University Press, 1989. Keynes: Open Univer
ISBN 0-335-09901-7.

\section{Nutritio}

Food Facts und Figures: a Comprehensive Guide to Healthy Eating. J Davies. Jice Gulde to Healthy Eating. J Davies, J Dickerson. (Pp x +128 ; $\{3.99$ paper-
back.) London: Faber and Faber, back. London: Faber and
1989. ISBN 0-571-15273-2.

Healthy Eating: Fact and Fiction. Ed A Bradley. Pp 176; questionnair appendix; figs; 66.95 paperback. London: Consumers' Association. 1989. ISBN 0-340-48875-1.

Nutrition Research Reviews 1988. Vo 1. General Editor R H Smith. P $\mathrm{P} x$. 285; figs; £35 paperback. / Cambridge:
Cambridge University Press, 1988. ISBN 0-521-37926-1.

Nutritional Medicine: a Case Management Approach. Ed G L Blackburn, S J Bell, JL Mullen. $(\mathrm{Pp} \mathrm{xv}+229$; figs; $£ 28.50$ paperback.) Philadelphia: Saunders, 1989. Distributed by Harcourt Brace Jovanovich. ISBN 0-7216-2233-X

World Review of Nutrition and Dietetics. Vol 58 . "Aspects of Childhood Nutrition." Volume and series
editor GH Bourne. (Pp x +165; figs; editor G H Bourne. (Pp x+165; figs; \{f1.70.) Basle: Karger, 1989. Distrib-
uted by John Wiley and Sons. ISBN 3-8055-4918-0.

\section{Obstetrics and gynaecology}

Current Reviews in Obstetrics and Gynaecologv. No 13. "Diabetic Pregnancy." $M$ Brudenell, $M$ Doddridge. Pp viii +152 ; figs; f19.50.) Edinhurgh: Churchill Livingstone, 1989 ISBN 0-443-02792-7.

Electronic Fetal Heart Rate Monitoring. a Practical Guide. PL Wood, HG Dobbie. (Pp x +86; figs; $\$ 8.95$ paperback.) London: Macmillan, 1989. back.) London: M
ISBN 0-333-47118-0.

Endocrine Disorders in Pregnancy. Ed $\mathrm{S} A$ Brody, K Ueland. (Pp xv +494 ; figs; $£ 62.75$.) Connecticut: Appleton and Lange, 1989. Distributed by Prentice-Hall International. ISBN 0-8385-2205-X

Fetal Monitoring: Physiology and Techniques of Antenatal and Intrapartum Assessment. Ed JAD Spencer. (Pp xvii +248 ; figs; £35.) Tunbridge Wells: Castle House, 1989. ISBN 0-7194-0135-6.

Positive Health Giuides. "Understanding Fndometriosis." C Hawkridge. Pp x + 164; figs: 55.99 paperack. London: Optima, 1989. ISBN 0-356 London: $154+7-5$.

Preparation and Advice for the MRCOG. VR Tindall, R H Martin RW Burslem. Pp xiii $+232 ; £ 9.95$ paperback.) Edinburgh: Churchill Livingstone, 1989. ISBN $0-4+3$ 035 $40-7$.

Year Book of Obstetrics and Gynecology 1989. Ed DR Mishell Jr, TH Kirschbaum, C.P Morrow. Pp xii 505; figs; $£ 40$. Chicago: Year Book Medical Publishers, 1989. Distributed by Wolfe Medical Publications. ISBN 0-8151-6011-9.

\section{Occupational medicine}

Practical Occupational Health. W Phoon. Pp $x+429$; figs; $\$ 30$. Sing pore: PG Publishing Pte, 1989. ISBN 9971-973-99-5.

\section{Oncology}

Current Problems in Tumour Pathology "Thyroid Tumours: Molecular Basi of Pathogenesis." Ed D Wynford Thomas, E D Williams. Series editor NA Wright, J G Azzopardi. (Pp vii + 169; figs; 445 .) Edinburgh: Churchil Livingstone, 1989. ISBN 0-44303568-7.

Cytokines in Cancer Therapy $\mathrm{FR}$ Balkwill. (Pp xvi+297; figs; $£ 18.50$ paperback.) Oxford: Oxford Univer sity Press, 1989. ISBN 0-19 261715-X

Urological and Genital Cancer. Ed R T D Oliver, JP Blandy, H H HopeStone. (Pp ix + 390); figs; $\{65$.) Oxford: Blackwell Scientific, 1989. ISBN 0-632-01702-3.

The Women's Cancer Book. C Faulder. Pp X $+220 ; \quad$ 5.99 paperback. London: Virago, 1989. ISBN 0-86068 993-X.

\section{Ophthalmology}

A Color Atlas of Ptosis: a Practical Guide to Evaluation and Manayement. J J Dutton. Pp ix +156; figs and colour plates; $\$ 50$.) Singapore: $P($ Publishing Pte, 1989. ISBN 9971 973-94-4.

Contact Lenses: Medical Aspects. M Ruben, CY Khoo. (Pp xii +212 ; figs and colour plates; $\$ 80$.) Singapore: $P$ Publishing Pte, 1989. ISBN 9971 973-93-6.

Gilaucoma: a Colour Mamual of Diagnosis and Treatment. J J Kanski, J A McAllister. $\mathrm{Pp}$ viii +152 ; figs and colour plates; $f 45$. London: Butterworth Scientific, 1989. ISBN 0-407worth Scient $016+4-9$.

PGis Ophthalmic Series. "Primary Angle Closure Glaucoma." R F Lowe. A S M Lim. (Pp xii +89; colour plates: price not stated.) Singapore: PG Publishing Pte, 1989. ISBN 981-3096$77-2$

\section{Oral medicine}

New Biotechnology in Oral Research Ed HM Mvers. (Pp $x+170$; figs 661.30.) Basle: Karger, 1989. Distributed by John Wiley and Sons. ISBN 3-8055-4916-4.

Orthopaedics

Arulsion and Stress Injuries of the

Musculoskeletal System. Ed J Tehranzadeh, A N Serafini, M J Pais. Pp ix + 126; figs; £33.) Basle: Karger 1989. Distributed by John Wiley and Sons. ISBN 3-8055-4917-2.

Infection in the Orthopaedic Patient. Ed R Coombs, RH Fitzgerald Jr. (Pp $x v+347$; figs; $£ 65$.) London: Butteworth Scientific, 1989. ISBN 0-407 $01316-4$

\section{Paediatrics}

Current Reviews in Paediatrics. Vol "Paediatric Hepatology." S Tanner Pp x+363; figs; E29.50.) Edinburgh: Churchill Livingstone, 1989. ISBN 0-443-03393-5.

A Practical Manual on Acute Paediat rics. Ed W C-L Yip, J S-H Tay. (Pp xvii $+450 ; \$ 60$.) Singapore: PG Pub lishing Pte, 1989. ISBN 981-309604-7.

\section{Parasitology}

MBL Lectures in Biology. Vol 9. "The Biology of Parasitism: a Molecular and Immunological Approach" Ed P' Englund, A Sher. (Pp xvi+544; figs; E0.) New York: Liss, 1988, Disrributed by John Wiley and Son SBN 0-8451-2208-8.

The Physiology and Biochemistry of Cestodes. J D Smyth, DP McManus. (Pp xi 398 ; £55.) Cambridge: Cam bridge University Press, 1989. ISBN $0-521-35557-5$.

Pathology

The Autopsy-Medical Practice and Public Policy. R B Hill, R E Anderson. Pp xxi+294; figs: $\{45$.) Boston: Butterworth Scientific, 1989. ISBN 0-409-90137-7.

Pharmacology

The Peripheral Actions of 5 Hydroxytroptamine. Ed J R Fozard Pr xxil1 +410; figs; $\mathrm{ft}$.) Oxford 0-19-261683-8.

Phusiciun's 1989 Drug Handhook. Springhouse Corporation. ( $P_{p} \mathbf{x}$ 1077; 117.95 paperback.) Pennsy vania: Springhouse Corporation. 1989. Distributed by Harcourt Brac Jovanovich. ISBN 0-87434-135-3.

Recent Advances in Clinical Pharmacology and Toxicology. $\mathrm{No}+$. Ed Turner, (iN Volans. (Pp xii +255 